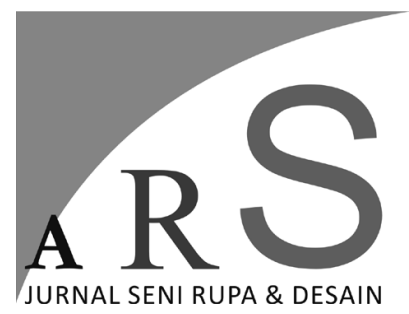

Volume 23 Nomor 3 September - Desember 2020

\section{PERANCANGAN AKSESORI FESYEN BERBAHAN RESIN DENGAN INSPIRASI MOTIF MARBLE}

\section{Tantri Ayunda Saputri}

Kriya Tekstil dan Mode, Fakultas Industri Kreatif, Telkom University, Jl. Telekomunikasi Jl. Terusan Buah Batu, Sukapura,

Kec. Dayeuhkolot, Bandung, Jawa Barat 40257

E-mail: tantriayun@gmail.com

\begin{abstract}
ABSTRAK
Fashion bukan hanya soal pakaian, gaya dalam fashion juga meliputi pelengkapnya. Di dunia fashion, aksesori digunakan sebagai pelengkap busana yang membuat seseorang terlihat lebih menarik sehingga aksesori kini sudah dianggap menjadi bagian penting dari fashion. Resin adalah suatu campuran yang kompleks dari ekskret tumbuhtumbuhan dan insekta. Resin dapat digunakan sebagai bahan dasar aksesori fashion karena bahannya mudah diolah dan tahan lama. Produk yang dihasilkan berupa anting, dan cincin yang memiliki ciri khas dan keunikan tersendiri.
\end{abstract}

Kata kunci : aksesori, anting, cincin, resin.

\title{
ABSTRACT
}

Fesyen Accessory Design Resin Materials With Marble Motive Inspiration. Fashion is not just about clothes, style in fashion also includes its complement. In the world offashion, accessories are used to complement clothing that makes someone look more attractive so that accessories are now considered an important part of fashion. Resin is a complex mixture of plant and insect excretions. Resin can be used as a basic material for fashion accessories because the material is easy to process and durable. The resulting products are in the form of earrings and rings that have their own characteristics and uniqueness.

Keywords: accessories, earrings, rings, resin. 


\section{Pendahuluan}

Fashion kini telah menjadi kebutuhan mendasar setiap orang. Semua orang di dunia ingin tampil lebih fashionable. Aksesori fashion kemudian menjadi solusi untuk menunjang penampilan setiap orang. Resin dapat digunakan sebagai bahan dasar aksesori fashion karena bahannya mudah diolah dan tahan lama. Dewasa ini bahan resin sedang menjadi trend dalam pembuatan aksesori.

Resin berasal dari produk hutan yang merupakan cairan getah lengket dari beberapa jenis pohon yang berasal dari hutan-hutan di Asia Tenggara. Namun, resin yang beredar di pasaran saat ini adalah resin sintetis yang berasal dari cairan kimia.

Sejarah mencatat bahwa resin ternyata adalah produk dagang yang paling tua dari Asia Tenggara dan sudah ada sejak zaman prasejarah. Sebelum Perang Dunia di awal tahun 1900 an, Indonesia bahkan memiliki beragam jenis resin yang berasal dari hutan-hutannya dan beberapa jenis resin seperti Terpentin yang berasal dari buah pinus ataupun resin berjenis Agathis telah menjadi komoditas yang bernilai ekonomi cukup tinggi (libratama.com). Masyarakat tanah air kurang begitu mengerti produk resin di luar dunia industri. Namun saat disodorkan nama damar, orang biasanya langsung mengerti. Damar dan resin adalah produk yang sama, hanya saja damar lebih banyak dikenal oleh masyarakat awam. Pohon-pohon di hutan Asia Tenggara ini biasanya dikenal dengan jenis dipterokarpa dan sangat banyak ditemukan di area dataran rendah. Di Indonesia sendiri, tumbuhan penghasil damar biasanya ditemukan di area Indonesia bagian barat. Sayangnya, damar sendiri masih dianggap sebagai produsen resin yang memiliki kualitas rendah untuk dunia industri, khususnya jika dibandingkan dengan resin yang berasal dari kopal ataupun terpentin.

Pada masa jayanya, saat damar masih menjadi bahan utama yang dicari dan dipergunakan dengan skala masif di dunia industri, hutan-hutan di tanah air banyak memasok bahan alam ini dari berbagai penjuru daerah. Tercatat, area penghasil damar terbesar di tanah air terdapat pada hutanhutan di area pulau Sumatera bagian selatan, barat dan Kalimantan bagian barat. Sementara untuk masa kini, kita dapat menemukan hutan-hutan pemroduksi damar di area sekitar pesisir selatan Sumatera, yakni di sekitar pesisir Krui, Lampung. Dikarenakan turunnya permintaan resin yang berasal dari alam, maka Indonesia pun dikenal sebagai satu-satunya negara penghasil damar di seluruh dunia. Pengguna damar dari area dalam negeri biasanya adalah pabrik-pabrik cat bermutu rendah sedangkan damar-damar berkualitas tinggi justru diekspor secara mentah ke Singapura untuk kemudian diproses kembali dan dijual sebagai dupa ataupun bahan baku pabrik cat di berbagai negara. Selain pabrik cat, beberapa industri seperti industri batik pun menggunakan damar sebagai salah satu bahan produksinya. Hanya saja pabrik cat lokal pun mulai menggunakan jenis resin-resin sintetis dari pabrik petrokimia. Hal ini membuat pasar resin alamiah dalam negeri dari damar pun semakin menurun seiring dengan semakin meningkatnya permintaan resin-resin sintetis. Aksesori berbahan resin yang beredar di pasaran saat ini pun terbuat dari resin sintetis atau kimia.

Menurut Setiawan dan Sulaksono (2012:1) bahwa " Resin atau dammar adalah suatu campuran yang kompleks dari ekskret tumbuhtumbuhan dan insekta. Secara fisis, resin (damar) ini biasanya keras, transparan plastis dan bila dipanaskan menjadi lembek. Secara kimiawi, resin adalah campuran yang kompleks dari asam-asam resinat, alkoholresinat, resinotannol, ester-ester dan resene-resene ". Jenis-jenis resin menurut Setiawan dan Sulaksono (2012:2) yaitu "Damar sesungguhnya (resin) adalah zat padat yang amorf atau setengah padat, tidak larut didalam air tetapi larut didalam alkohol atau pelarut organik lainnya dan membentuk sabun dengan alkali. Damar gom (Gummi resina) yaitu campuran alami dari gom, minyak dan resin. Sering disebut juga damar lender. Oleoresin yaitu campuran alami yang homogen dari resin didalam minyak menguap. Balsamum adalah campuran dari resin dengan asam sinamat atau benzoin atau kedua-duanya atau ester-esternya dengan minyak menguap “.

\section{Manfaat Perancangan}

Perancangan ini memiliki manfaat sebagi berikut:

- Perancangan ini diharapkan dapat menambah wawasan dan pengetahuan mengenai produk aksesori berbahan resin. 
- Menambah ilmu bagi pembaca tentang pembuatan aksesori berbahan resin mulai dari perancangan hingga proses produksi.

\section{Objek Perancangan}

Aksesori yang akan dibuat cenderung soft aksesori berupa anting dan cincin dengan desain yang modern, elegan, dan mewah. Target audience dari perancangan ini adalah wanita dewasa berusia 25-35 tahun.

\section{Perancangan Eksploratif}

Terdapat 6 (Enam) langkah atau tahapan kegiatan perancangan eksploratif, mengadopsi dari Duerk (1993): maka enam langkah Itu antara lain: (1) identifikasi fakta, (2) memilih persoalan prioritas, (3) memutuskan tujuan, (4) menetapkan kriteria, (5) memilih konsep dan (6) presentasi. Dalam kegiatan eksplorasi perancangan aksesoris berbasis resin ini, maka keenam langkah itu direduksi ke dalam: 1) menetapkan konsep, 2) pra perancangan, 3) membuat alternatif desain, 4) eksplorasi dan hasil.

\section{Konsep}

Konsep perancangan ini terinspirasi dari fenomena alam unik yang terjadi di pulau Vaadhoo atau biasa juga disebut pulau dengan laut bertabur bintang. Fenomena tersebut merupakan reaksi kimia yang disebut bioluminescence, yang muncul jika mikro organisme yang hidup di dalam air bertemu dengan oksigen sehingga menghasilkan visual menyerupai marble.

\section{Pra Perancangan}

Perancang dilakukan dengan membuat sketsa digital. Perancang membuat beberapa alternatif desain anting dan cincin. Langkah selanjutnya adalah eksplorasi motif marble. Berikut beberapa bahan dan sketsa dalam perancangan ini:

\section{- Bahan}

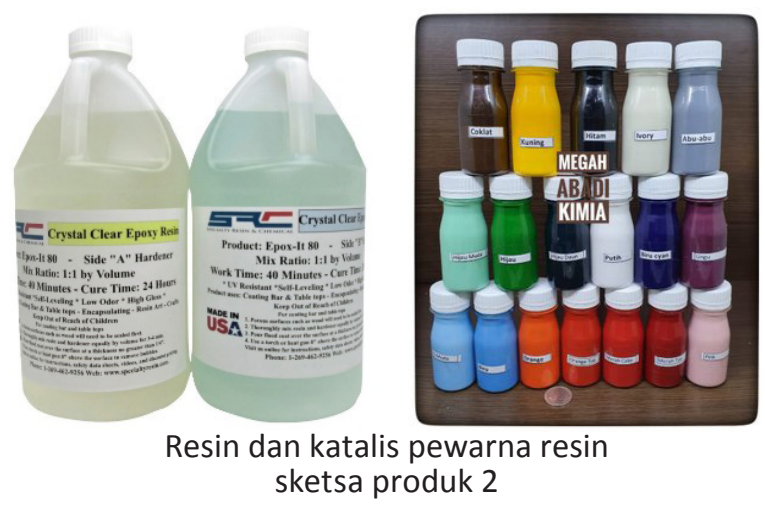

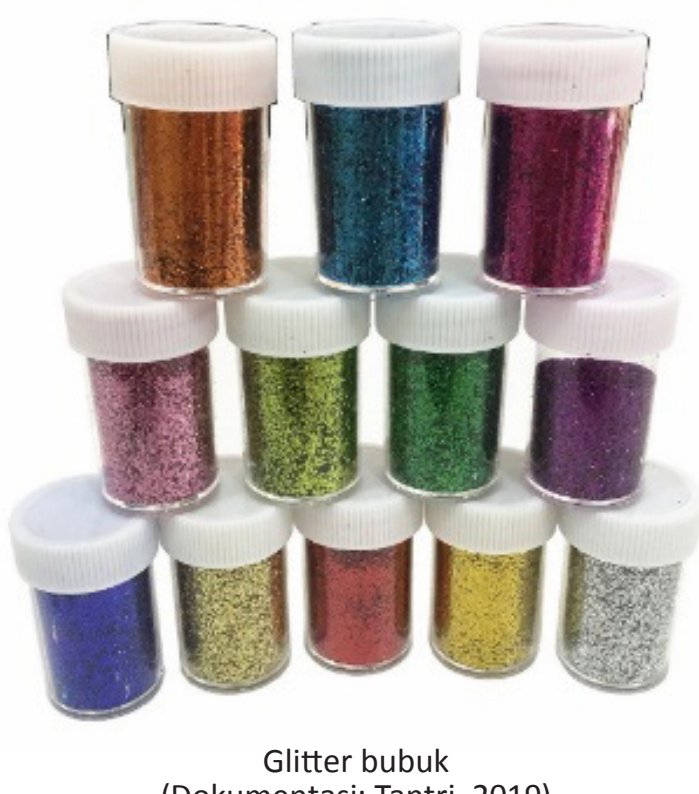

(Dokumentasi: Tantri, 2019)

\section{- Alternatif Desain}
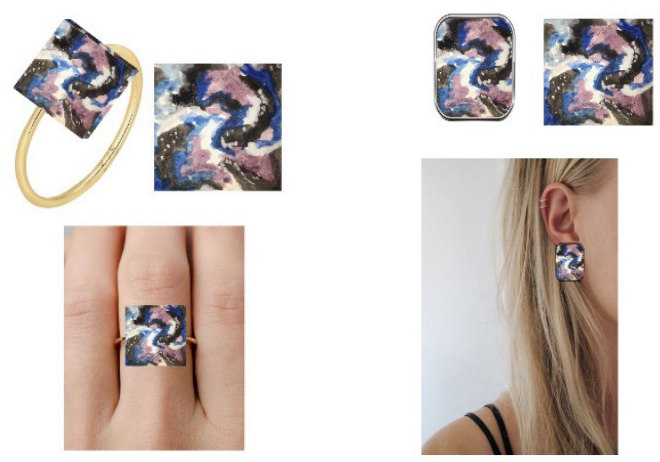

sketsa produk 1 sketsa produk 2 (Dokumentasi: Tantri, 2019)
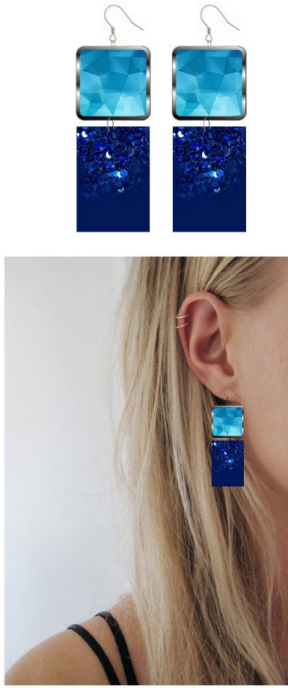

Sketsa produk 3

(Dokumentasi: Tantri, 2019) 


\section{Eksplorasi}
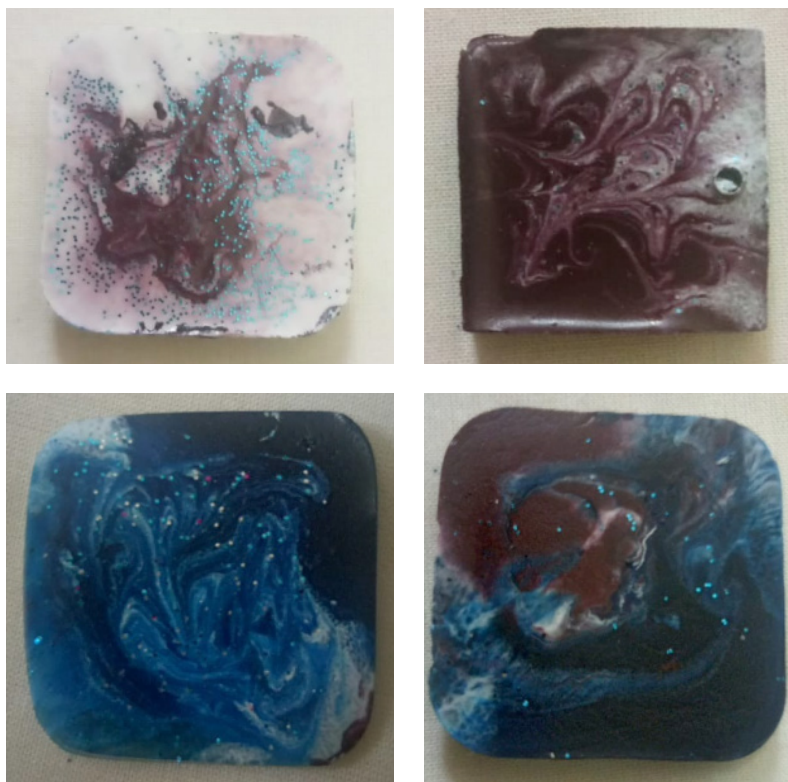

(Dokumentasi: Tantri, 2019)

\section{Hasil Perancangan}

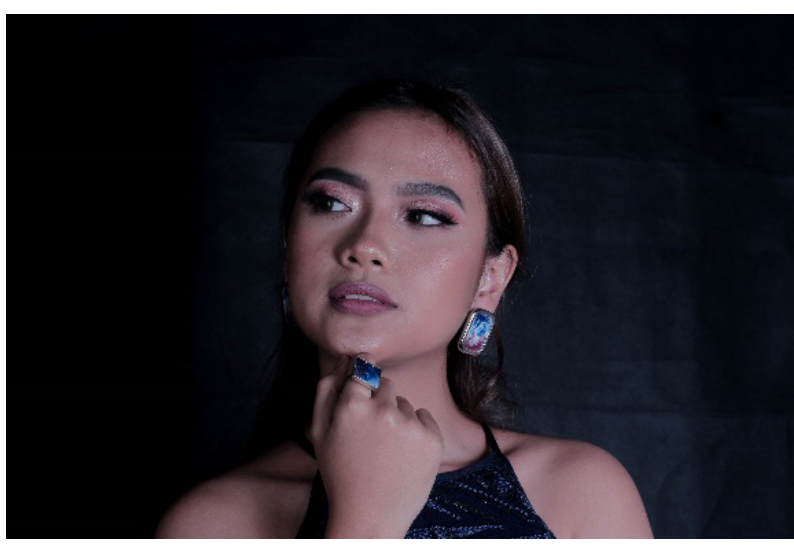

Produk 1

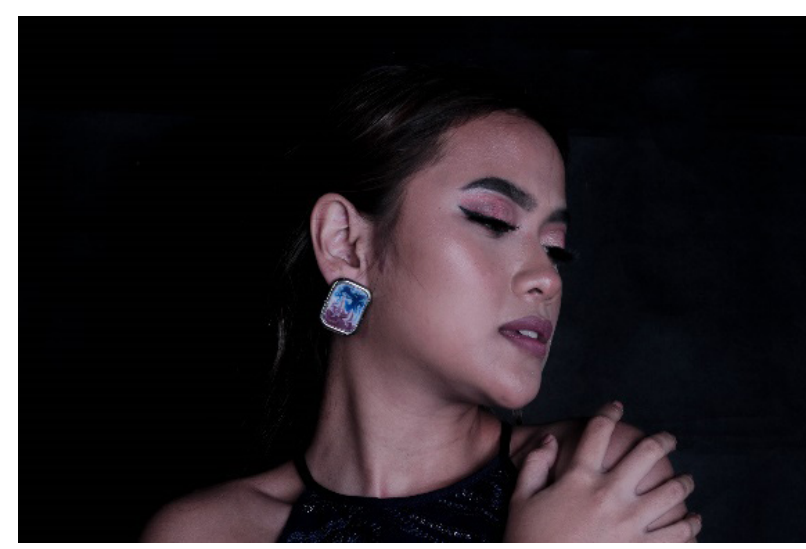

Produk 2
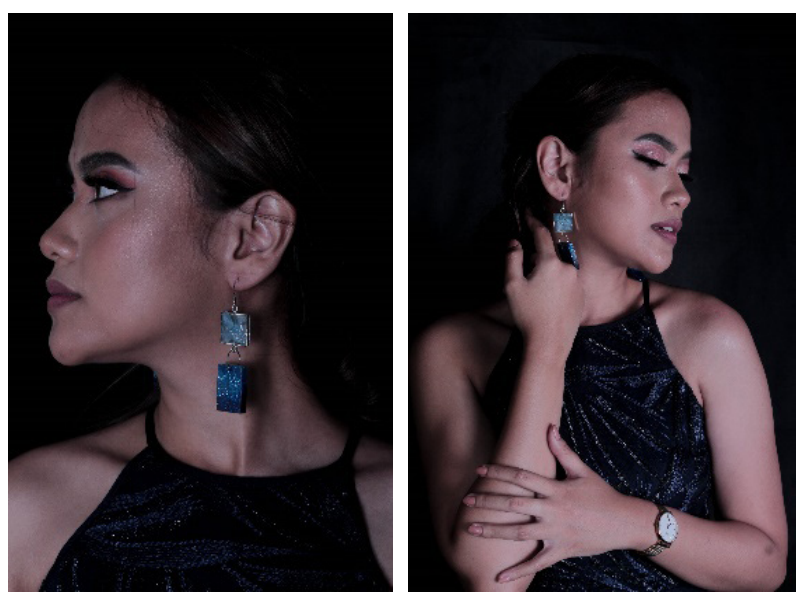

Produk 3

(Dokumentasi: Tantri, 2019)

\section{Kesimpulan}

Kesimpulan dari perancangan ini yang berjudul perancangan aksesori fesyen berbahan resin dengan inspirasi motif marble ini melalui berbagai tahapan, tahapan eksplorasi data, perencanaan (pembuatan thumbnail, tightissue) hingga tahap perwujudan (visualisasi). Tahapan eksplorasi merupakan tahapan menggali informasi mengenai pembuatan motif dan penakaran campuran resin dan katalis. Tahapan perencanaan merupakan tahapan menganalisis data seperti referensi model aksesori, pembuatan beberapa desain aksesori. Tahapan perwujudan (visualisasi) merupakan tahap pembuatan aksesori yang desainnya sudah terpilih dari beberapa alternatif. Dalam perancangan ini, penulis menyimpulkan bahwa dalam merancang sebuah aksesori khususnya anting dan cincin dibutuhkan wawasan tentang model dan bahan aksesori yang sedang trend. Perancangan aksesori dengan bahan resin sangat berpotensi karena sifat resin yang mudah dibentuk dan daya tahannya yang kuat.

\section{Saran}

Dalam proses pembuatannya, perlu menambahakan katalis sehingga resin tidak mengeras setelah dicetak. Untuk mengatasi hal tersebut, sebaiknya selalu tambahakan katalis setelah menuang resin. Takaran resin yang sebaiknya digunakan yaitu $50 \mathrm{ml}$ resin dan 8 tetes katalis, hal ini dikarenakan resin paling cepat mengeras dengan takaran ini, dan tidak ada perbedaan hasil jadi dengan takaran-takaran lain. 
Dalam mengaduk campuran resin, katalis, dan pewarna harus diaduk sampai benar-benar rata. Karena pigmen warna tidak bisa mengering jika tidak tercampur rata dengan resin dan katalis.

\section{Daftar Pustaka}

Balfas, J.(2008). Kandungan Resin Pada Kayu Gaharu Tanaman. Jurnal Pusat Litbang Hasil Hutan.

Duerk, D.P. (1993). Architectural Programming, Information Management for Design. New York: Van Nostrand Reinhold.

Setiawan, Fajar dan Agung Sulaksono. (2012). RESIN. Jurnal Tingkat Sarjana bidang Seni rupa dan Desain

Libratama.com, Mengenal Sejarah Resin, 23 Mei 2014 